\title{
Determination of Antimicrobial Activity of Corchorus olitorius Leaf Extracts
}

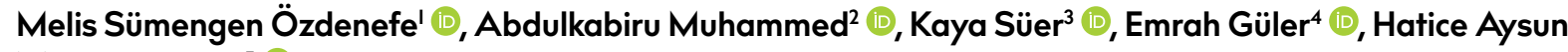 \\ Mercimek TakcI $^{5}$ (D)
}

'Department of Biomedical Engineering, Near East University, Nicosia, Cyprus

2Department of Food Engineering, Near East University, Nicosia, Cyprus

${ }^{3}$ Department of Infectious Diseases and Clinical Microbiology, Near East University, Nicosia, Cyprus

${ }^{4}$ Department of Microbiology and Clinical Microbiology, Near East University, Nicosia, Cyprus

${ }^{5}$ Department of Molecular Biology and Genetics, Kilis 7 Aralık University, Kilis, Turkey

ORCID IDs of the authors: M.S.Ö. 0000-0003-0804-9557; A.M. 0000-0002-32I0-I75X; K.S. 0000-0002-2565-3425; E.G. 0000-00021635-005I; H.A.M.T. 0000-0002-3388-II53.

Cite this article as: Sümengen Özdenefe M, Muhammed A, Süer K, Güler E, Mercimek Takcı HA. Determination of Antimicrobial Activity of Corchorus olitorius Leaf Extracts. Cyprus J Med Sci 2018; 3(3): 159-63.

\section{BACKGROUND/AIMS}

The aim of this study was to determine the antimicrobial (antibacterial and antifungal) activity of the Corchorus olitorius (C. olitorius) leaf extracts, obtained from different regions of the Turkish Republic of Northern Cyprus.

\section{MATERIAL and METHODS}

A total of seven samples of seven different brands of the dried plant material (Corchorus olitorius leaves) were collected from Lefkosa, Kyrenia, Guzelyurt, Lefke, Iskele, and Gazimagusa. The leaf extracts were extracted with the methanol, ethanol, chloroform, and hexane solvent (1:10 [weight/volume]) at room temperature for 3 days under shaking conditions. After evaporation, the samples were suspended in methanol, ethanol, chloroform, and hexane at the final concentration of $100 \mathrm{mg} / \mathrm{mL}$. The antimicrobial activity was evaluated using the disc diffusion method. The negative control included pure ethanol, methanol, chloroform, and hexane for each respective sample (methanol, ethanol, chloroform, and hexane extracts). The positive control included tetracycline for S. aureus, S. epidermidis, and B. subtilis, ciprofloxacin for E. coli, Klebsiella spp., and E. cloacae; nystatin for C. albicans; and teicoplanin for E. faecalis.

\section{RESULTS}

Antimicrobial activity was only displayed by hexane leaf extracts toward B. subtilis and S. aureus.

\section{CONCLUSION}

At the end of this study, it was observed that the methanol, ethanol, and chloroform extracts of the C. olitorius leaf displayed no antibacterial activity. Only one of the extracts, the hexane extract, showed the antimicrobial activity against both B. subtilis and $S$. aureus. Therefore, the leaf of $C$. olitorius can be used to treat people having infections caused by $S$. aureus and B. subtilis.

Keywords: Antimicrobial activity, Corchorus olitorius leaf, medicinal plant

\section{INTRODUCTION}

Corchorus olitorius ( $C$. olitorius) is known as both a medical and a fiber plant from the family Tiliaceae. Commonly referred to as jute plant, it is known as molehiya in North Cyprus, Turkey, and Philippines, moroheiya in Japan (I), Jew's mallow in Hebrew, and bush okra in Nigeria and other West African countries (2). According to the authors, this species is native to India or the Indian sub-continent (Sri Lanka, Burma, etc.), but due to the presence of a variety of wild relatives in Africa and the fact that it has always been the leading leafy vegetable for the people of Nigeria, Sudan, Ivory Coast, Benin, Cameroon, etc., some authors now believe that the origin of C. olitorius is in fact Africa (3).

Corchorus olitorius leaves are known to be rich in nutrients such as iron, phosphorus, calcium, potassium, and carotene (4). It is used in the treatment of fever, tumors, pectoral pains, dysentery, aches, enteritis, cystitis, piles, and dysuria (2). Apart from its nutritional advantages, the sticks of C. olitorius can be gathered to be used as both fuel and for producing charcoal and gun powder (5). 
Medicinal plants have been known since the ancient times and have been used ever since to add flavor to food, to preserve food, to help promote good health, and to treat and prevent medical aliments (diseases), including infections. The reason for this are certain factors that include high costs of modern medicines, an onset of side effect when conventional pharmaceutical drugs are used, the rise in human population, and decreasing efficacy of modern synthetic drugs. Also, problematic are the emerging pathogenic microorganisms resistant to modern antibiotics and reduced effectiveness of these antibiotics. Several plants used traditionally have a potential antimicrobial property, and this has encouraged the optimism of scientists about the future of phytoantimicrobial agents $(2,6,7)$.

\section{MATERIAL and METHODS}

A total of seven samples of seven different brands of the dried plant material ( $C$. olitorius leaves) were collected from Lefkosa, Kyrenia, Guzelyurt, Lefke, Iskele, and Gazimagusa. All the C. olitorius leaf samples acquired from different regions of Northern Cyprus were grinded into powder using a porcelain mortar and then stored in the refrigerator at $4^{\circ} \mathrm{C}$ until further use. The leaf extracts were extracted with the methanol, ethanol, chloroform, and hexane solvents $(\mathrm{I}: 10[\mathrm{w} / \mathrm{V}])$ at room temperature for 3 days under shaking conditions. After 72 hours, all the samples were filtered using the Whitman filter paper, and then all the methanol and ethanol leaf extracts were concentrated using a rotary evaporator, while the hexane and chloroform leaf extracts were evaporated under a fume hood, and then the extraction yield was calculated based on the dry weight of the leaves. After the evaporation of solvents, samples were suspended in methanol, ethanol, chloroform, and hexane at the final concentration of $100 \mathrm{mg} / \mathrm{mL}$.

The antimicrobial activity was evaluated using the Kirby-Baver disc diffusion method (8). For the antimicrobial test, Staphylococcus aureus, Escherichia coli, Enterococcus faecalis, Bacillus subtilis, Staphylococcus epidermidis, Enterobacter cloacae, Klebsiella spp., and Candida albicans were used. The antimicrobial activity for bacteria and yeast was performed on the Mueller-Hinton Agar. Sterile antimicrobial blank discs were placed strategically away from each other, and $15 \mathrm{~mL}$ of the appropriate samples was pipetted onto seven of the blank antimicrobial disc. Pure methanol, ethanol, chloroform, and hexane were used as negative control based on solvent of extraction. On the agar plate, the number I represented the Mulihiya, number 2 Othello, number 3 Karaca, number 4 Olkobirlik, number 5 Bafra, number 6 Baharyolu, and number 7 the Ender molokhia sample. As for the positive control, tetracycline (Bioanalyse Limited, $30 \mu \mathrm{g}$ ) was used as the positive control for B. subtilis, S. aureus, and $S$. epidermidis. Ciprofloxacin (Bioanalyse Limited, $5 \mu \mathrm{g}$ ) was used as the positive control for $E$. coli, Klebsiellaspp., and Enterobacter cloacae. Nystatin (Oxoid, 100 units) was used as the positive control for C. albicans, while teicoplanin (Bioanalyse Limited, $30 \mu \mathrm{g}$ ) was used as the positive control for E. faecalis. All samples were incubated at $37^{\circ} \mathrm{C}$ for 48 hours. Following the incubation, the clear zones around the antimicrobial disc were examined and their diameters were measured.

The minimum inhibitory concentrations (MIC) of the C. olitorius leaf extracts that showed antimicrobial activity against test microorganisms were determined. This analysis was performed based on fact that the lowest inhibitory concentration determines to effective on test microorganisms. In this test, the 12.5, 25, 50,75 , and $100 \mathrm{mg} / \mathrm{mL}$ concentrations of the Baharyolu hexane leaf extract were investigated for their inhibitory effects against B. subtilis and S. aureus.

\section{RESULTS}

The highest extraction yield was found in the methanol extract, as an average $10.324 \%$. The ethanol and chloroform extracts had an average extraction yield of $4.589 \%$ and $3.463 \%$, respectively. The lowest extraction yield was recorded in the hexane extract with an average yield of $2.883 \%$ (Table I).

TABLE I. Extraction yield (\%) for all leaf extracts

\begin{tabular}{lcccc} 
Name of the Molehiya Product & Ethanol Extracts (\%) & Methanol Extracts (\%) & Chloroform Extracts (\%) & Hexane Extracts (\%) \\
\hline Olkobirlik & 4.15 & 9.962 & 2.975 & 3.062 \\
Othello & 5.873 & 12.624 & 3.298 & 3.732 \\
Mulihiya & 4.007 & 9.648 & 3.554 \\
Baharyolu & 4.748 & 10.599 & 1.84 \\
Bafra & 4.523 & 10.171 & 2.405 & 0.27 \\
Karaca & 4.043 & 8.564 & 4.361 & 3.29 \\
Ender & 4.781 & 10.706 & 3.2964 & 8.87 \\
\hline
\end{tabular}

TABLE 2. Diameter of the inhibition zone $(\mathrm{mm})$ (antimicrobial activity) of the methanol, ethanol, and chloroform leaf extracts ( $100 \mathrm{mg} / \mathrm{mL} \mathrm{concen}$ tration, $15 \mu \mathrm{L}$ ) against Bacillus subtilis, Staphylococcus aureus, and Staphylococcus epidermidis

\section{Samples of Dried Molokhia}

\begin{tabular}{|c|c|c|c|c|c|c|c|c|c|}
\hline $\begin{array}{l}\text { Microorganisms } \\
\text { Tested }\end{array}$ & Mulihiya & Othello & Karaca & Olkobirlik & Bafra & Baharyolu & Ender & $\begin{array}{l}\text { Methanol, Ethanol, } \\
\text { Chloroform (NC) }\end{array}$ & Tetracycline (PC) \\
\hline B. subtilis & - & - & - & - & - & - & - & - & 32 \\
\hline S. epidermidis & - & - & - & - & - & - & - & - & - \\
\hline
\end{tabular}


All the leaf samples of the methanol, ethanol, and chloroform extracts displayed no antibacterial and antifungal activity against all the bacterial and fungus species used (Tables 2-5). As seen from Table 6, antimicrobial activity was only displayed by the hexane leaf extracts toward B. subtilis $(10 \mathrm{~mm}$ ) and S. aureus $(12 \mathrm{~mm})$ (Figure I, 2).
As seen from Table 7, it was encountered any inhibitory effect of the hexane extract on B. subtilis. It was observed to low inhibitory effect for all tested concentrations on $S$. aureus as compared with the positive control. However, the growth of $S$. aureus was inhibited at the $12.5 \mathrm{mg} / \mathrm{mL}$ Baharyolu hexane leaf concentra-

TABLE 3. Diameter of the inhibition zone $(\mathrm{mm})$ (antimicrobial activity) of the methanol, ethanol, chloroform, and hexane leaf extracts (I00 $\mathrm{mg} / \mathrm{mL}$ concentration, $15 \mu \mathrm{L}$ ) against E. coli, Klebsiella spp., and E. cloacae

Samples of Dried Molokhia

\begin{tabular}{|c|c|c|c|c|c|c|c|c|c|}
\hline $\begin{array}{l}\text { Microorganisms } \\
\text { Tested }\end{array}$ & Mulihiya & Othello & Karaca & Olkobirlik & Bafra & Baharyolu & Ender & $\begin{array}{l}\text { Methanol, Ethanol, } \\
\text { Chloroform, Hexane (NC) }\end{array}$ & Ciprofloxacin (PC) \\
\hline E. coli & - & - & - & - & - & - & - & - & 30 \\
\hline E. cloacae & - & - & - & - & - & - & - & - & 34 \\
\hline
\end{tabular}

TABLE 4. Diameter of the inhibition zone $(\mathrm{mm})$ (antimicrobial activity) of the methanol, ethanol, chloroform, and hexane leaf extracts ( $100 \mathrm{mg} / \mathrm{mL}$ concentration, $15 \mu \mathrm{L}$ ) against C. albicans

\section{Samples of Dried Molokhia}

\begin{tabular}{|c|c|c|c|c|c|c|c|c|c|}
\hline $\begin{array}{l}\text { Microorganisms } \\
\text { Tested }\end{array}$ & Mulihiya & Othello & Karaca & Olkobirlik & Bafra & Baharyolv & Ender & $\begin{array}{c}\text { Methanol, Ethanol, } \\
\text { Chloroform, Hexane (NC) }\end{array}$ & Nystatin (PC) \\
\hline
\end{tabular}

TABLE 5. Diameter of the inhibition zone $(\mathrm{mm})$ (antimicrobial activity) of the methanol, ethanol, chloroform, and hexane leaf extracts (I00 $\mathrm{mg} / \mathrm{mL}$ concentration, $15 \mu \mathrm{L})$ against E. faecalis

\section{Samples of Dried Molokhia}

\begin{tabular}{|c|c|c|c|c|c|c|c|c|c|}
\hline $\begin{array}{l}\text { Microorganisms } \\
\text { Tested }\end{array}$ & Mulihiya & Othello & Karaca & Olkobirlik & Bafra & Baharyolu & Ender & $\begin{array}{l}\text { Methanol, Ethanol, } \\
\text { Chloroform, Hexane (NC) }\end{array}$ & Teicoplanin (PC) \\
\hline E. faecalis & - & - & - & - & - & - & - & - & 35 \\
\hline
\end{tabular}

TABLE 6. Diameter of the inhibition zone $(\mathrm{mm})$ (antimicrobial activity) of the hexane leaf extracts ( $100 \mathrm{mg} / \mathrm{mL}$ concentration, $15 \mu \mathrm{L})$ against BacilIus subtilis, Staphylococcus aureus, and Staphylococcus epidermidis

\section{Samples of Dried Molokhia}

\begin{tabular}{|c|c|c|c|c|c|c|c|c|c|}
\hline $\begin{array}{l}\text { Microorganisms } \\
\text { Tested }\end{array}$ & Mulihiya & Othello & Karaca & Olkobirlik & Bafra & Baharyolv & Ender & Hexane (NC) & Teicoplanin (PC) \\
\hline S. aureus & 8 & - & 9 & 9 & 10 & 12 & 8 & - & 25 \\
\hline S. epidermidis & - & - & - & - & - & - & - & - & - \\
\hline
\end{tabular}

\section{TABLE 7. Minimal inhibitory concentration of the Baharyolu hexane leaf extract}

\section{Samples of Dried Molokhia}

\section{Concentration of the}

\begin{tabular}{|c|c|c|c|c|c|c|c|}
\hline Hexane Extract & $12.5 \mathrm{mg} / \mathrm{mL}$ & $25 \mathrm{mg} / \mathrm{mL}$ & $50 \mathrm{mg} / \mathrm{mL}$ & $75 \mathrm{mg} / \mathrm{mL}$ & $100 \mathrm{mg} / \mathrm{mL}$ & Hexane (NC) & Tetracycline (PC) \\
\hline B. subtilis & - & - & - & - & - & - & $32 \mathrm{~mm}$ \\
\hline S. aureus & $8 \mathrm{~mm}$ & $9 \mathrm{~mm}$ & $9 \mathrm{~mm}$ & $\| \mathrm{mm}$ & $12 \mathrm{~mm}$ & - & $25 \mathrm{~mm}$ \\
\hline
\end{tabular}




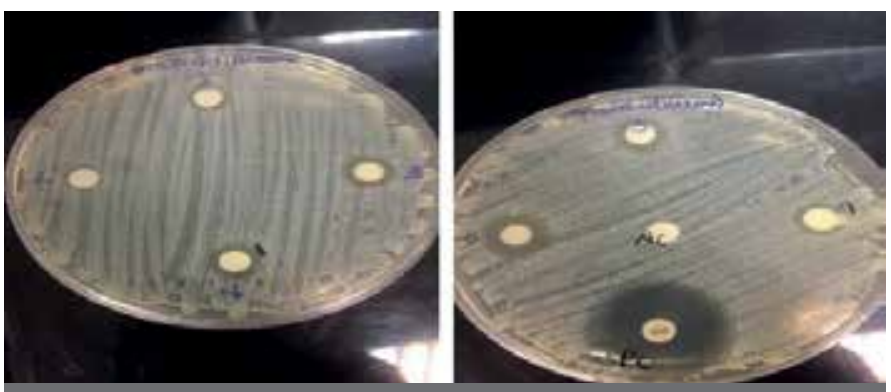

FIGURE I. Antibacterial activity of the hexane extract toward Staphylococcus aureus
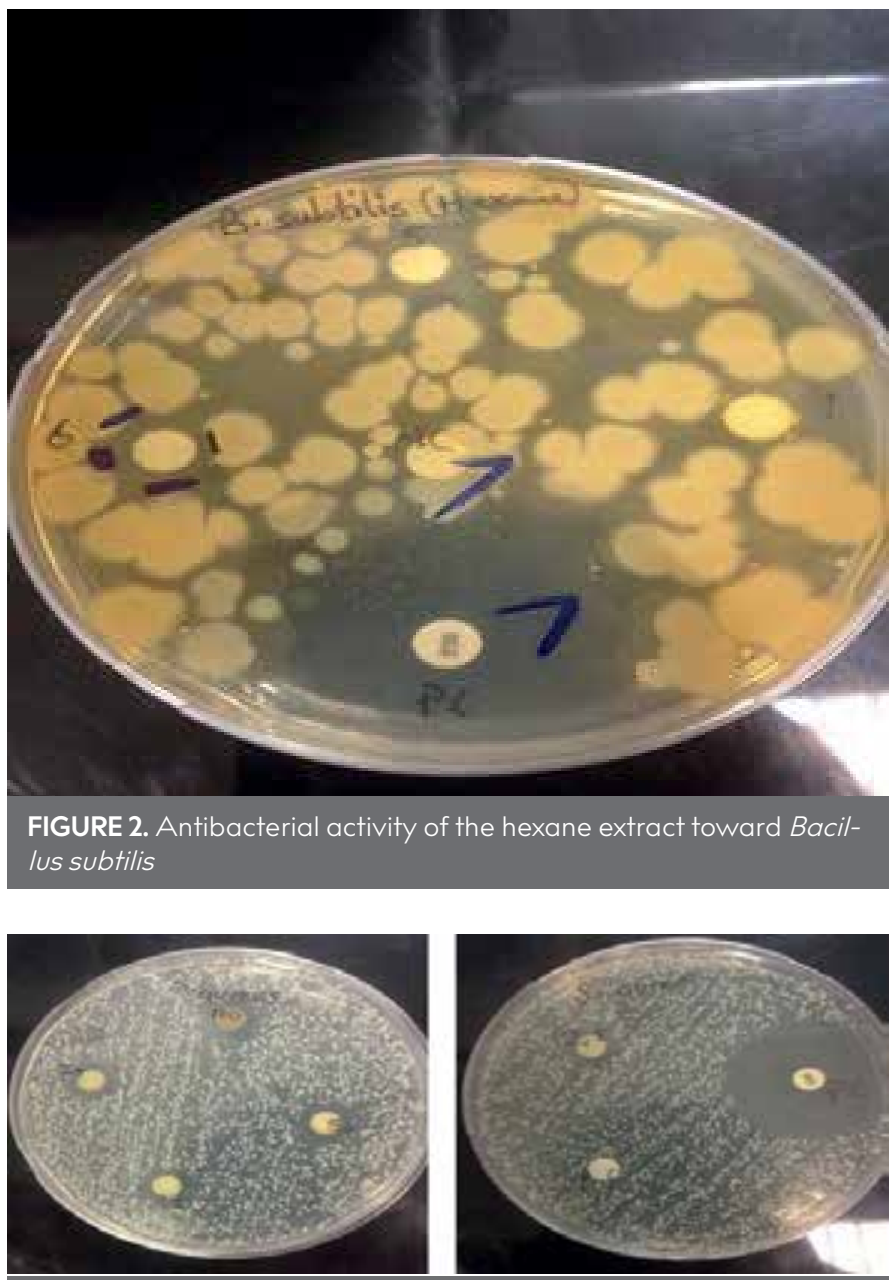

FIGURE 3. Clear indication of inhibition toward the growth of $S$. aureus at different concentrations of the Baharyolu hexane leaf extracts
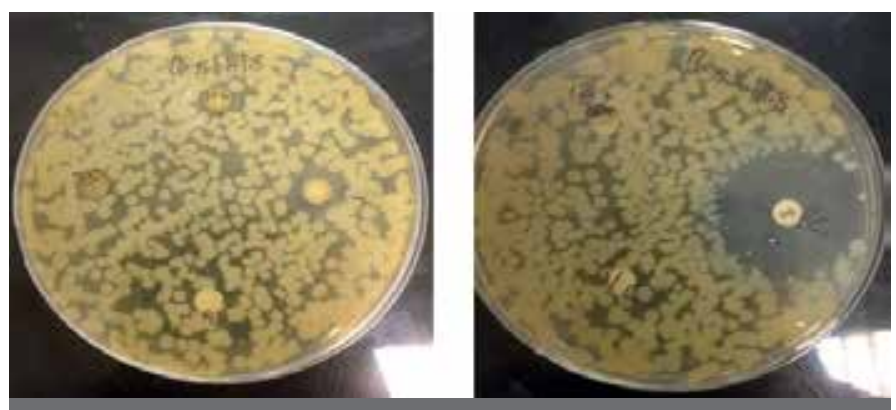

FIGURE 4. No inhibition toward the growth of B. subtilis at different concentrations of the Baharyolu hexane leaf extract tion (Figure 3,4). Thus, the MIC value of the Baharyolu hexane leaf extract effective against $S$. aureus was $12.5 \mathrm{mg} / \mathrm{mL}$. This result was similar to the inhibition zones recorded for the antimicrobial test.

\section{DISCUSSION}

The average extraction yields were $10.324 \%$ for methanol extracts, $4.589 \%$ for ethanol extracts, $3.463 \%$ for chloroform extracts, and $2.88 \%$ for hexane extracts. Sellami et al. (6) recorded the hexane extract (2.5\%) with the lowest extraction yield between the ethanol (6.42\%) and aqueous extract (10\%) of $C$. olitorius leaves. This can be attributed to the fact that hexane is a non-polar solvent with a polarity index of 0.0. Also, different extraction yields (\%) have been reported by llhan et al. (9). The yields of extraction for the petroleum ether extract, methanol extract, and ethyl acetate+water extract were found as $8 \%, 3.8 \%$, and $2.2 \%$, respectively.

The fact that all chloroform, ethanol, and methanol leaf extracts displayed no antimicrobial activity is not in line with other studies. Ullah et al. (I0) concluded that the methanolic extract of different edible vegetables from Bangladesh showed antibacterial activity with the zone of inhibition ranging from 5 to $28 \mathrm{~mm}$. The methanolic leaf extract of $C$. olitorius displayed the least antibacterial activity against Shigella boydi $(6 \mathrm{~mm})$ and Vibrio mimicus $(5 \mathrm{~mm}$ ). The methanolic leaf extract of C. olitorius displayed antibacterial and antifungal activities, with the diameters of zone inhibition ranging between II and $20 \mathrm{~mm}$ (9). In addition, Soykut et al. (II), reported that the C. olitorius ethanol leaf extract did not display any significant antimicrobial activity toward all tested bacterial and fungal strains.

The different finding was also stated for $C$. olitorius methanolic extract from Adegoke and Adebayo. The antibacterial activity of methanolic extracts against S. aureus, E. coli, K. pneumonia, and $S$. typhi. was observed at higher concentrations, such as $62.5,125,250$, and $500 \mathrm{mg} / \mathrm{mL}$. In these concentrations, the inhibition zone diameters against $S$. aureus were found as $5.0 \pm 0.3$ $\mathrm{mm}, 6.0 \pm 1.0 \mathrm{~mm}, 7.0 \pm 0.6 \mathrm{~mm}$, and $8.4 \pm 0.2 \mathrm{~mm}$, respectively (2).

The zones of inhibition displayed by the hexane leaf extract against both $S$. aureus $(12 \mathrm{~mm})$ and B. subtilis $(10 \mathrm{~mm})$ were considerably lower than those displayed by the antibiotic (tetracycline) against those same bacteria. This can be attributed to the fact that the extract used was crude preparations. Further purifications or concentration enhancements might be needed to obtain more active compounds. Sellami et al. (6), also observed that the antibacterial activity displayed by different plant extract was relatively lower than the positive control (ampicillin). The $C$. olitorius hexane extract showed a low bactericidal activity with the diameter of inhibition $<15 \mathrm{~mm}$ against $S$. xylosus (6).

In our study, the antimicrobial activity observed against S. aureus is similar to previous studies. It was reported to observe the antibacterial activity against $S$. aureus, these studies used the leaf and flower combination (essential oil from $C$. olitorius, $12.6 \pm 0.9 \mathrm{~mm}$ at $6 \mathrm{mg}$ ) (12) or just the leaf (methanolic extract of $C$. olitorius, $10.9 \pm 0.02 \mathrm{~mm}$ at $1.0 \mathrm{mg} / \mathrm{mL}$ ) (7).

Also, the obtained antimicrobial activity against $B$. subtilis showed similarity to the results detected in another study car- 
ried out by Driss et al. (12), where the zone of inhibition was recorded at $16.6 \pm 1.3 \mathrm{~mm}$ at $6 \mathrm{mg}$. It therefore stands to reason that an increase in the concentration of leaf extract used in this study might lead to a higher zone of inhibition.

S. aureus is the causative organism for urinary tract infections, food poisoning, abscesses, and respiratory infections. As for that, $B$. subtilis is the reason of food poisoning. So, the observed antimicrobial activity against these microorganisms is important to clinical treatment based on the medicinal plant.

The antimicrobial activity against tested gram-negative bacteria was not observed. This fact is similar to other studies concerning the antimicrobial activity against gram-positive and gram-negative bacteria. This is because the possession of an outer membrane by gram-negative bacteria that covers the cell wall limits the dilution of hydrophobic compounds, thus making them less likely to be affected by an antibiotic $(9,12)$.

Al-Yousef et al. (13) reported that the leaf and stem dry oils from C. olitorius showed an antibacterial and antifungal activity against all tested pathogen microorganisms. $S$. aureus was moderately sensitive with the $16 \mathrm{~mm}$ diameter of the inhibition zone against the obtained leafdry oil (I3).

Table 7 shows the minimum inhibition concentration results of the $C$. olitorius hexane extracts against $B$. subtilis and $S$. aureus. Since there is no previous research on the hexane leaf extract of $C$. olitorius, the authors are not able to compare the results against anything.

As a result of our study, the methanol, ethanol, and chloroform extracts of the C. olitorius leaf were found to display no antibacterial activity against test microorganisms. However, the hexane extract developed an inhibitory effect against both B. subtilis and S. aureus. Especially, it was observed in the case of $S$. aureus that an increase in the extract concentration lead to an increase in the zone of inhibition based on the hexane extract. Therefore, the leaf of C. olitorius can be used by people with urinary tract infections, abscesses, skin infections, respiratory infections, endocarditis, osteomyelitis, and food poisoning to help them fight against infections caused by pathogenic microorganisms such as $S$. aureus and B. subtilis.

Ethics Committee Approval: Ethics committee approval was not required for this laboratory based study.

Informed Consent: N/A.

Peer-review: Externally peer-reviewed.

Author contributions: Concept - M.S.O., A.M.; Design - M.S.O., A.M., H.A.M.T.; Supervision - M.S.O.; Resource - M.S.O., K.S., E.G.; Materials -
M.S.O., K.S., E.G.; Data collection and/or Processing -M.S.O., A.M., E.G.; Analysis and/or interpretation - M.S.O., A.M., K.S., H.A.M.T.; Literature search - M.S.O., A.M.; Writing - M.S.O., A.M.; Critical Reviews - M.S.O., K.S., H.A.M.T.

Acknowledgements: The authors would like to thank Near East University and Hospital.

Conflict of Interest: The authors have no conflicts of interest to declare.

Financial Disclosure: The authors declared that this study has received no financial support.

\section{REFERENCES}

I. Ozturk N, Savaroglu F. Antioxidant Activities of Molokhia (Corchorus olitorius L.) Extracts. Environ Earth Sci 20ll; 535-43.

2. Adegoke A, Adebayo-Tayo B. Phytochemical composition and antimicrobial effects of Corchorous olitorius leaf extracts on four bacterial isolates. J Med Plants Res 2009; 3: 155-9.

3. Loumerem M, Alercia A. Descriptors for jute. Genetic Resource Crop Evolution 2016; 63: II03-II. [CrossRef]

4. Azuma K, Nakayama M, Koshioka M, Ippoushi K, Yamaguchi Y, Kohata $K$, et al. Phenolic antioxidants from the leaves of Corchorus olitorius leaf. J Agric Food Chem 1999; 47: 3963-6. [CrossRef]

5. Gangaiah B. Jute. New Delhi: Indian Agricultural Research Institute; 2008. Available From: URL: http://nsdl.niscair.res.in/ispui/bitstream/123456789/537/I/Jute\%20-Formatted.pdf. [CrossRef]

6. Sellami M, Ghariani B, Louati H, Miled N, Gargouri Y. Biological Activities of Extracts of Different Spices and Plants. Int J Curr Eng Technol 2013; 3: 105I-60.

7. Barku YAV, Opoku-Boahen Y, Owusu-Ansah E, Dayie NTK, Mensah FS. In-Vitro Assessment of Antioxidant and Antimicrobial Activities of Methanol Extracts of Six Wound Healing Medicinal Plants. J Nat Sci Res 2013; 3: 74-80.

8. Baver AW, Kirby WMM, Sherris JC, Turck M. Antibiotic Susceptibility Testing by a Standardized Single Disk Method. Am J Clin Pathol 1966; 45: 493-6. [CrossRef]

9. İlhan S, Savaroğlu F and Çolak F. Antibacterial and Antifungal Activity of Corchorus olitorius L. (Molokhia). Int J Nat Eng Sci 2007; I: 59-61.

10. Ullah MO, Haque M, Urmi KF, Zulfiker AHM, Anita ES, Begum M, et al. Anti-bacterial activity and brine shrimp lethality bioassay of methanolic extracts of fourteen different edible vegetables from Bangladesh. Asian Pac J Trop Biomed 2013: I-7. [CrossRef]

II. Soykut G, Guvenir M, Susevir S, Becer E, Calis I and Suer K. Antibacterial and antifungal effects of Corchorus olitorius leaf extracts on ten standard strains. J Biotechnol 2017; 2565: 44-II6.

12. Driss D, Kaoubaa M, Mansour RB, Kallel F, Abdelmalek B, Chaabouni SE. Antioxidant, Antimutagenic and Cytotoxic Properties of Essential Oil from Corchorus olitorius leaf flowers and Leaf. Free Radic Antioxid 2016; 6: 34-43. [CrossRef]

13. Al-Yousef HM, Amina M, Ahamad SR. Comparative study on the chemical composition of Corchorus olitorius/Leaf and stem dry oils. Biomed Res 2017; 28: 458I-7. 